\title{
O USO DE FERRAMENTAS DE VOZ ANDROID E IOS PARA DESENVOLVER INGLÊS PARA FINS ACADÊMICOS (EAP): HABILIDADES DE FALA PARA FALANTES NÃO NATIVOS DE INGLÊS
}

\author{
USO DE HERRAMIENTAS DE VOZ ANDROID E IOS PARA DESARROLLAR INGLES \\ PARA FINES ACADEMICOS (EAP): HABILIDADES DE SPEECH PARA LOS \\ SPEAKERS INGLES NO NATIVOS
}

\author{
THE USE OF ANDROID AND IOS VOICE TOOLS TO DEVELOP ENGLISH FOR \\ ACADEMIC PURPOSES (EAP): SPEAKING SKILLS FOR NON-NATIVE SPEAKERS \\ OF ENGLISH
}

RESUMO: ESAP se refere ao inglês para uma disciplina específica, cuja especificidade inclui vocabulário técnico ou especial, usos variados da gramática acadêmica, como voz passiva e nominalização, e gêneros profissionais e acadêmicos específicos que são produzidos pela disciplina. Pensando em como aumentar a confiança e a competência da língua inglesa em falantes não-nativos, este estudo tem como principal objetivo analisar como o uso de ferramentas de gravação de voz Android e iOS pode desenvolver habilidades de inglês falado em alunos de um curso de Letras Inglês no Brasil. O estudo apontou que as ferramentas de gravação de voz oferecem aos alunos oportunidades para produzir resultados orais, pois permitem que os alunos pratiquem suas habilidades de conversação dentro e fora da sala de aula, gerando mais confiança e coragem para usar o ESAP em sala de aula.

PALAVRAS-CHAVE: Gravadores de voz. Inglês para fins acadêmicos. Fala.

RESUMEN: ESAP se refiere al inglés para una disciplina específica, cuya especificidad incluye vocabulario técnico o especial, usos variados de la gramática académica, como la voz pasiva y la nominalización, y géneros profesionales y académicos específicos que se producen por disciplina. Pensando en cómo aumentar la confianza y la competencia del idioma inglés en hablantes no nativos, este estudio tiene como objetivo principal analizar cómo el uso de herramientas de grabación de voz. Android e iOS puede desarrollar habilidades de inglés hablado en los estudiantes de un Curso de letras en inglés en Brasil. El estudio señaló que las herramientas de grabación de voz ofrecen a los estudiantes oportunidades para producir resultados orales, ya que permiten a los estudiantes practicar sus habilidades conversacionales dentro y fuera del aula, generando más confianza y valor para ESAP en el aula.

PALABRAS CLAVE: Grabadoras de voz. Inglés con fines académicos. Hablar.

${ }^{1}$ Universidade Laureate International (UNIRITTER), Campus FAPA, Porto Alegre - RS - Brasil. Professora do Curso de Graduação em Educação. ORCID <http://orcid.org/0000-0002-7450-3079>. E-mail: Simone.lancini@uniritter.edu.br 
ABSTRACT: ESAP refers to English for a specific discipline, which specificity includes technical or special vocabulary, varying uses of academic grammar such as passive voice and nominalization, and particular professional and academic genres which are produced by the discipline. Thinking in how to increase the English speaking confidence and competence of non-native speakers, this study has aims to analyze how the use of Android and iOS voice recording tools can develop students' speaking English skills in an English Letters graduation course in Brazil. The study pointed out that voice recording tools provide learners with opportunities to produce oral output, since they allow students to practice their speaking skills inside and outside the classroom, bringing up more confidence and courage to use ESAP in classroom.

KEYWORDS: Voice recorders. English for academic purposes. Speaking.

\section{Introduction}

Speaking is one of the four fundamental skills for effective communication in any language and setting, mainly, when we refer to English Letters undergraduate students who need to use such skill to communicate in English while in classes, to explain contents and also, to take part of academic life, as lectures and presentations. Besides, English is universally known as a means of communication all over the world, as in the internet.

My current job has been working with non-native English speakers, in a Brazilian university, as an undergraduate professor of the English Letters Course. At first, I noticed students have had difficulties to express themselves in English, some of them, are just afraid of exposing them in front of the colleagues. Secondly, as a professor, I've also realized there are some reasons for the blockades of speaking English in class, one of them, is the kind of English they need to use the most in class, which is the English for Specific Academic Purposes (ESAP). According to Wakeland (2013) ESAP refers to English for a specific discipline, this specificity includes technical or special vocabulary, varying uses of academic grammar such as passive voice and nominalization, and particular professional and academic genres which are produced by the discipline. ESAP is a sub-branch of the field English for Academic Purposes (EAP), Evans and St. John (1998), EAP can be defined as being any English teaching that is related to a study purpose, usually taught in study settings, particularly but not exclusively in tertiary education. More simply put, EAP and the 'specific' element referred to, is usually less concerned about 'what' language to teach and more concerned with teaching learners 'how' to use language in particular situations and tasks.

Flowerdew and Peacock (2001b) also claim that speaking English skill is a vital skill to learn, but that sadly this skill area is usually neglected. EAP is not immune to this phenomenon, 
where academic speaking skills are not often explicitly taught and are expected to happen in a vacuum. Similar conclusions are found amongst my undergraduate students and researches carried out by Ostler (1980), for instance, who feels students lack the basic proficiency for speaking successfully and so far, university has not given enough explicit instruction in these areas (OSTLER, 1980). Thirdly, I've also observed, as well as Boonkit (2010), Trent (2009) and other related studies, another reason for the majority of undergraduate students being unable to speak English, mainly EAP confidently, is the lack of confidence in terms of anxiety about making mistakes while speaking in public.

Based on the question of how to increase the speaking confidence and competence of undergraduate students, I've searched for ways of doing that. Considering students nowadays are more connected into technology than ever, not only the students, but also professors, and the cellphone is in our hands most part of the day, I've used cellphone voice recorders as a tool to develop English for Specific Academic skills. Thus, this study has as main aim to analyze how Android and iOS voice recorder tools can develop and improve English for Specific Academic Purposes Speaking skills of non-native English speakers in the English Letters undergraduate course.

In order to provide effective instruction, it is important to keep in mind that the use of Android and iOS voice recording tools should be aligned with instructional goals and pedagogy along with students' proficiency level. As the purpose of this research study is to develop EAP speaking skills, it's also important to take into account the students' proficiency level. The analyzed group of English Letters undergraduate students has different proficiency levels, many of them, hesitate whenever they have to speak in public. Considering it, each students' limitation was respected, the use of voice recorder tools tends to give them the opportunity to speak EAP issues, listen to their voices, record and rerecord, regardless the English level.

\section{The importance of speaking ESAP}

Since we are babies we have been prepared to speak before learning how to read and write. Any given human spends more time interacting orally with language rather than using it in its written form. Speaking in English is not an easy task because speakers should know many meaningful components like pronunciation, grammar, vocabulary, fluency and comprehension. Speaking is also integrated with other language skills, as it helps learners develop their vocabulary and grammar skills, improving their written skills. 
Considering English for Specific Academic Purposes (ESAP) speaking skills, Bingol, Mart, Yildiz and Celik (2014) point out that there are two main important points in practicing such skill: a) to help international students reach their full academic needs and potential and b) to expose these students to the expectations and requirements of the faculties in terms of target situation needs and academic culture. Communication skills help students in their study, career development, job interviews, workplace and social networking. The Warwick University (2017) states in its website that students need practical and deeper knowledge about the subject they are learning. For that, they need to learn how to ask questions and discuss what they want and think relevant.

Good communication skills also build strong friendships and gives confidence. However, all is possible when someone respects others, communicate when it is important. At the university, many courses now include assessed presentation and even negotiation and discussion tasks, which require English speaking skills. Activities which require speaking skills at the university:

- engage actively in seminar discussions.

- give a paper/presentation at a seminar - sometimes the paper may be assessed by the tutor, your peers or yourself (or perhaps a combination of all three of these).

- answer questions from your tutor or fellow students.

- discuss your course with other students informally, outside the classroom.

- get help from fellow students or the tutor about essay titles.

- $\quad$ socialize with other students by participating in clubs and societies, or even just by talking to others within your accommodation.

- discuss issues with your landlord/landlady if you have private rented accommodation.

- $\quad$ ask for help if and when you need it, and understand the advice you are given.

- attend a job interview in English.

In addition, if you are a research student, you will need to have competent spoken communication skills in order to:

- communicate effectively with your peers, both socially and professionally. 
- 'network' effectively at conferences and other research events.

- be successful in your Ph.D. viva (oral examination).

- engage effectively in teaching activities, to the satisfaction of your students, as may be required by your department.

- conduct any research required and communicate with your supervisor.

You can see that time and effort need to be invested to meet all of these requirements. Therefore, EASP speaking skills need to developed in a daily basis.

\section{Understanding English for specific academic purposes}

The field of English for Academic Purposes (EAP) can be divided into two subbranches: English for General Academic Purposes (EGAP) and English for Specific Academic Purposes (ESAP). The first, EGAP, is attributed to the teaching of language and skills that are common over all disciplines. The second, ESAP, focus more on specific language and tasks regarding particular areas as fields of knowledge. As the focus of this study is to develop academic speaking skills in disciplines of an English Letters undergraduate course program, the sub-branch of such study is English for Specific Academic Purposes (ESAP). The writer also highlights the importance of distinguishing English for Widdowson (1983), who relates this specificity to a dichotomy between education and training, where education has to do with the development of general skills necessary for academic success, while training is seen as more advanced or practical skills, as in occupations settings. Such different definitions are useful since EAP is not a monolithic phenomenon and has developed at different speeds in particular countries and settings with specific needs of users dictating course content and level.

The specificity in ESAP includes technical or specialist vocabulary, varying uses of academic grammar such as passive voice and nominalization, and particular professional and academic genres which are produced by the discipline. Basturkman (2013) states that this division links into the distinction between English for Specific Purposes (ESP) between wideangled and narrow-angled courses, the former being premised on the idea that generic language skills can be transferred across many contexts and the latter being premised on the idea that students can benefit and become more motivated from language and content that are specific to their needs. Supporting the specificity, Hyland (2002) points out the importance of introducing students' linguistic cultures of their disciplines, rejecting generic approaches that claim that 
basic skills and language conventions exist across disciplines. Recently, researches as Paltridge (2009) have shown a shift in the acceptance of specificity in the field of EAP and reviews how the use of corpora and genre analysis had changed previous views towards teaching ESAP by revealing greater complexity than acknowledged beforehand.

Unfortunately, there has been some resistance to the idea of ESAP both from within the field of EAP and from subject specialists. In the field, authors such as Hutchinson and Water (1987) did not see any need for subject-specific language instruction since they do not consider different frequencies of technical vocabulary or particular grammatical structures with greater need or difficulty in learning them. Part of the resistance from subject specialists usually comes in the form of misunderstandings about the role of the ESAP teacher and from different academic perspectives and practices. Nevertheless, there are evidences from needs analysis towards teaching language which is relevant to students' content courses.

\section{Factors influencing learners' English speaking skills}

Boonkit (2010) explains there are a number of factors relating to English speaking skills effectiveness, such as pronunciation, vocabulary and collocations. Upon providing students with a range of situations and frequent speaking tasks, student's speaking fluency tend to improve a lot (TAM, 1997).

Confidence and competence also lead to strengthens English speaking skills. Patil (2008) claims that building up the learner's confidence to eliminate fear of making mistakes it's some priority teachers should consider in order to make the learner feel more comfortable with their language usage. Yet, Bailey (2005) and Songsiri (2007) points out that confidence and competence in speaking could be developed from appropriate syllabus design, methods of teaching and enough tasks and materials.

For having effectiveness of speaking, Bailey (2005) and Songsiri (2007) also point out a number of elements such as listening skills, sociocultural factors, affective factors and other linguistic and sociolinguistic competence, as grammatical, discourse, sociolinguistic and strategic competence. According to their studies, non-native speakers' learners must have an understanding of words and sentences, that is, they must understand how words are segmented and stressed in particular ways. This grammatical competence helps speakers to understand English language structures accurately and unhesitatingly, contributing to their fluency, as a consequence, it develops confidence in speaking. 
Ahmadi e Leon (2017) claim there are some speaking skills problems teachers can come across while assisting students in classes. Inhibition, lack of topical knowledge, low participation and mother-tongue use are some of them. Inhibition is usually one of the first problems that students have to deal with in class, mainly because they are worried about making mistakes and fearful of criticism. Besides, they are ashamed of the other's students' attention toward themselves. According to Harmer (2003, p. 289) "language classroom can also create inhibitions and apprehension for the students". Rivers (1968) mentions that learners often don't participate because they probably don't have anything to say, which is due to unappropriated topics selected by the teacher. In ESAP classes it usually happens, as a professor, I have noticed this is because of the ESAP illiteracy. Other authors, Baker and Westrup (2003), state learners have difficulties to give opinion about academic issues, as it needs a specific vocabulary to apply and an accurate grammar.

In order to solve some of the difficulties mentioned before, Mazouzi (2013) says students' activities should be designed based on an equivalence between fluency and accuracy achievement. Classroom practice can help learners develop their communicative competence. Taking such practice into account, the use of tools as voice recorders can be used in a variety of ways in academic language instructions to provide learners opportunities to produce oral output "as they allow language students to practice and enhance their speaking skills outside the classroom while receiving feedback on their performance" (POP; TOMULETIU; DAVID, 2011, p. 1199).

\section{The use of cell phone voice recorder tools in ESL classes}

As Aoki (2014) mentions, voice recording tools have been used in language instruction as a way of giving learners the opportunity to produce oral output, since such tools can be used both inside and outside classroom. Besides, students can receive a prompt feedback on their speaking skills performance. According to some studies, the output is necessary for second language learning development. As Swain and Lapkin (1995) have pointed out the importance of such outputs, since it leads to students' fluency. One of the ways suggested by the authors is that by recording, learners can listen, access and edit their own recorder material.

Centuries ago, cassette tapes were used as voice recording tools. Users had to carry around them in order to record and listen to their oral production. Fortunately, today, due to the voice recording tools and the easy access of the internet over the world, there has been several 
possible ways of using voice recording tools in language instruction. Technology has run so fast, that students are able to record their voice and share audio files, such as voice e-mails, podcasts and audio-blogs have popularly been incorporating in speaking drills inside and outside classroom.

Technology widespread has also made self-learning, mainly languages learning, more effective in terms of oral/speaking skills. According to Aoiki (2014), recording activities allow feedback from teachers and peers, allowing a positive view and also influence on the learners' performance. Lately, asynchronous feedback and asynchronous interactions using voice recording tools, as opposed to synchronous in-class, having a feedback and positive response to the speaking skills, have gained popularity in language learning classes. Asynchronous voice recording activities promote peer-to-peer interactions inside and outside classroom, besides enabling teachers to give students a personalized feedback.

According to McIntosh, Braul and Chao (2003) studies, peer-to-peer asynchronous interaction gives more enthusiasm for the students. Yet, most of their experiences with asynchronous activities have given the students the advantages of listening to themselves and paying attention to their own mistakes. Likewise, the authors Pop, Tomuletiu, and David (2011) have used asynchronous audio interaction tools in EFL class for adults in Romania, where there where basically the same challenges, that is, learners from different levels and stages, besides lack of confidence. As a result of the experiment, students were more positive and engaged in the asynchronous interactional activities.

According to Stannerd (2013), another great aspect of voice recording tools is that they can be used to contribute towards an e-portfolio. The Council of Europe suggests using portfolios and e-portfolios as assessment tools. The e-portfolio has three parts: a passport, a biography and a dossier. The passport provides information about the student's level in the languages he/she speaks and is based on the Common European Framework of Reference. The biography is done through a list of "can do" statements that represent what the student can do with the language. The dossier part of the e-portfolio is a collection of evidence of the student's level. It can include all types of digital artefacts like blogs, mind maps, video and of course audio recordings.

\section{Methodology}


This study, which aims to analyze how Android and iOS voice recorder tools can develop and improve English for Academic Purposes Speaking skills of non-native English speakers in the English Letters undergraduate course, is based on empirical evidence undertaken in the discipline of Applied Linguistics of the English Language in the English Letters Undergraduate Course in a Brazilian private university.

In this research, the researcher is called the active agent, which is different of other researches, in which the researchers were mere observers. This is also an action research, since it provides research and action in a single process, where the actors involved participate together with the researchers, to reach the reality in which they are inserted, identifying collective problems, seeking and experiencing solutions in real situations (THIOLLENT, 1997).

The study counted on the participation of 15 students enrolled in the discipline of Applied Linguistics of the English Language in the English Letters Undergraduate Course. Along two weeks, students have learned more about the different types of English teaching methods and approaches. Taking this into account, students were persuaded to choose a different English teaching method or approach, read and study deeply about the specific one chosen, then talk about it using a voice recorder tool, instead of just simply presenting it orally in front of the colleagues.

Mobile apps have replaced many electronic devices in the past few years and voice recorder is one of them. There are many iPhone and smartphone apps that can record voices quite decently. Examples of best voice recording tools for iOS and Android were suggested to the students, which are: a) Voice Recorder HD; HT Professional Recorder and iTalk Recorder Premium; for iPhones, and Smart Voice Recorder and Voice Recorder 2018 for other smartphones. Just as in oral presentations they are used to, students were encouraged to talk about the method, giving examples and sharing their opinions about the advantages and the disadvantages of using it. After doing so, students were asked to share through phones and/or e-mail the recordings with the whole group. Each student had to listen, take notes, if needed, ask questions, in order to understand about the methods and approaches better, after doing so, they were stimulated to answer a quiz prepared by the professor. It follows bellow the voice recorders suggested tools for iOS and Android:

\section{Voice recorder $\mathrm{HD}(\mathrm{iOS})$ :}

iOs, which can be found in App Store, is considered one of the best voice recording apps for iPhone and iPad. The app has been designed for school/college students, lecturers, 
journalists, businessmen and even audio professionals and sound engineers. Besides, the tool is efficient in recording and rendering high quality sounds. The app offers bluetooth recording, background recording, unlimited time recording and iCloud sync. Another important point is that it is possible to share audio files via Airdrop, upload to SoundCloud or DropBox and it has got many such features. (BADU, 2016).

\section{HT Professional voice recorder (iOS):}

HT Professional Recorder is another voice recording apps for iPhone that can be used by both students and other professionals who work or need to use voice recorder and their activities. Its easy interface helps to record and edit lectures, conferences, business meetings on the iPhone. It is also possible to take notes while the app is recording important lectures. Yet, it records conversation from a distance and automatically skip silence. It can even record whispers. Students can record and send audio files (as WAV attachment and up to 30-minute length) via email. Finally, it can be navigated easily to bookmarks for faster review. (BADU, 2016).

\section{iTalk Recorder premium voice recorder (iOS)}

iTalk Recorder Premium is another voice recording app for iPhone, mainly due to an easier user interface. Its feature-rich application provides recording quality- $11.025 \mathrm{kHz}$, $22.05 \mathrm{kHz}$, or $44.10 \mathrm{kHz}$. Also, students can easily mail audio files from iTalk Recorder Premium. The tool also has the possibility of direct file sharing, AirDrop, SoundCloud and Share Sheet. iTalk Recorder always creates quality audio tracks irrespective of the challenges. (BADU, 2016).

\section{Smart Voice Recorder (Android)}

According to the developers, this app was made for longer recordings, and one of its main features is related to that. Considering it was created for recordings that are long, Smart Voice Recorder presents a silence removal on-the-fly option, which means it will automatically detect periods of silence and erase them, so you won't be bothered with them when listening to your audio. So, it is an option for the aim of this study, as it is not necessary to rerecord all the 
time. Also, it is good for lectures and classes recordings. The length of recording is determined only by the space available on your device, and it has the option of working in the background with display off. It is quite easy to use and its interface reminds of simpler times, which might not be met with agreement by those who love the modern material design, but there are people that will encourage this approach. (HINDY, 2018).

\section{Voice recorder 2018 (Android)}

Voice Recorder 2018 is a fairly standard and uninteresting voice recorder app. That may be its best feature. You can do the basics like record, trim your audio, export to MP3, save your recordings, playback old recordings, and share. That's all it does, basically. You can do some stuff like adjust the sample rate, but most of the app is straightforward. This is a decent option for people who just want something simple and free to record something. (HINDY, 2018).

\section{Analyses}

The students who took part of this study had positive reactions toward the method. Most of them, expressed a better oral performance since they have analyzed the use their own vocabulary and grammar in their recordings, which is also what authors as Stillwell et al. (2010) have analyzed, an increase in complexity after recording. However, there were some students who did not want to take part of the task, especially because they were afraid of judgments or critics on their speaking performance. Despite it, I attempted to motivate them in all the process, giving them feedback individually and causing a self-reflection on their own recordings. On the other hand, most of them were successful and enjoyed not being exposed at first and felt more confident to talk about academic issues. As long as classes were running, students were more communicative, interactions and participations have started. Students were engaged in the topic and opposed to what Tuan \& Mai (2015) observed on studies, they were not inhibited, considering they had knowledge about the academic topic in discussion.

It is possible to say the use of voice recorders for ESAP speaking skills development also contributed to students' independence and responsibility of their own learning. This was possible because as Aioki (2014) states, such tools create a sense of accomplishment in students. They considered the voice recording tools extremely helpful, not only for the discipline itself, but for other ESAP disciplines. Yet, many of them started using the tools at home to practice 
their speaking skills, mainly those who are shy to speak in public, and also, for rehearsal before other discipline's oral presentations and lectures. Generally, they highlighted the fact that communication was encouraged and classes were more exciting and pleasant with the use of the tools.

\section{Conclusion}

The present study which aims to analyze how the use of Android and iOS voice recording tools can develop students' speaking English skills in an English Letters graduation course in Brazil, showed the use of Android and iOS voice tools can bring interesting results to ESAP classes, as more participation, independence, responsibility and encouragement for undergraduate students. It is also a different way of helping students to improve their fluency and oral skills. Voice recordings also give the students a real motivation to reflect on their work, as it is the students who decide which of their recordings they want to put forward for formal presentations.

We also saw English for Academic Purposes (EAP) field is divided into two subbranches, which are: English for General Academic Purposes (EGAP) and English for Specific Academic Purposes (ESAP). EGAP, is attributed to the teaching of language and skills that are common over all disciplines. On the other hand, ESAP focus more on specific language and tasks regarding particular areas as fields of knowledge (WIDDOWSON, 1983). Due to this, it is possible to claim this study focus on the ESAP field, considering we are talking about disciplines of an English Letters undergraduate course program.

As Boonkit (2010) claims in his studies, there are a number of factors relating to English speaking skills effectiveness, such as pronunciation, vocabulary and collocations, factors I have noticed along classes. However, as the author states, upon providing students with a range of situations and frequent speaking tasks, student's speaking fluency tend to improve a lot. The use of technological tools can help in this process, as such tools have also made distant language and self-learning more effective in terms of oral/speaking skills. Speech recognition and synthesis technologies are gaining popularity in these settings and they may be considered as voice recording tools. According to the analyzed data, voice recordings also give the students a real motivation to reflect on their work, as it is the student who decide which of their recordings they want to put forward for formal presentations. 
The practice can help learners develop their communicative competence and tools, such as voice recorders, can be used in a variety of ways in academic language instructions to provide learners opportunities to produce oral output. The empiric study also showed when students' activities are well designed based on an equivalence between fluency and accuracy achievement, speaking skills tend to improve more and more.

The fact that communication needs to be encouraged using a range of tools and didactic in academic environments. By doing it, classes tend to be more excited and pleasant, besides the tools can develop the necessary ESAP techniques, special vocabulary, different academic grammar structures such as passive voice and nominalization, and particular professional and academic genres which are produced by the discipline.

\section{REFERENCES}

AOKI, S. Potencial of Voice Recording Tools in Language Instruction. TESOL Web journal, 2014.

BADU, J. Best Voice Recording Apps for iPhone in 2018. Disponível em: https://blogs.systweak.com/2018/02/record-your-voice-now-with-these-7-best-iphone-apps/. Acesso em: jan. 2019.

HARMER, J. The Practice of English Language Teaching: the 3th edition. London and New York: Longman, 1991.

HINDY, J. 10 Best Voice Recorder Apps for Android. Disponível em: https://www.androidauthority.com/best-voice-recorder-apps-for-android-615332/. Acesso em: jan. 2019.

LITTLEWOOD, W. Communicative Language Teaching. Cambridge: Cambridge University Press, 2007.

POP, A.; TOMULETIU, E. A.; DAVID, D. EFL speaking communication with asynchronous voice tools for adult students. Procedia-Social and Behavioral Sciences, 15, p. 1199-1203. 2011.

STANNERD, R. Recognizing the power of voice recording. Disponível em: https://www.theguardian.com/education/2013/feb/26/voice-recording-english-languageteaching. Acesso em: jan. 2019.

WAKELAND, L. Development of an English-for-specific-academic-purposes Course for Music Students. Centre for Applied English Studies: Hong Kong: Hong Kong University, 2013. 
WARWICK University. Spoken Communication Skills. Disponível em:

https://text.www2.warwick.ac.uk. Acesso em: jan. 2019.

TUAN, N. H.; MAI, T. N. Factors Affecting Students' Speaking Performance at LE Thanh High School. Asian Journal of Educational Research, v. 3, n. 2, p. 12 - 200, 2015.

\section{Como citar este artigo:}

LANCINI, Simone. O uso de ferramentas de voz Android e iOS para desenvolver inglês para fins acadêmicos (EAP): habilidades de fala para falantes não nativos. Rev. EntreLínguas, Araraquara, v. 5, n. 1, p. 63-76, jan./jun. 2019. E-ISSN: 2447-3529. DOI: 10.29051/el.v5i1.12633

Submetido em: 30/12/2018

Revisões requeridas: 26/02/2019

Aprovado em: 15/03/2019

Publicado em: 30/04/2019 